\title{
Anti-extremism and Anti-terrorism in Legislation of Tajikistan: Problems of Application
}

\author{
Valijon Abdukhamitov *, Rano Abdullayeva \\ Faculty of Law, Russian-Tajik Slavonic University, 30 M. Tursunzoda St., Dushanbe, 734025, Tajikistan
}

\begin{abstract}
The paper considers the issues of implementing the standards of the international legislation on religious and extremist crimes in the national legislation of the Republic of Tajikistan. With regard to its ideology the category of extremism is reflected in the criminal law through the concept of extremist crime: crime for political, ideological, racial, national or religious hatred or hostility reasons or crimes resulting from hatred or hostility towards any social group. According to the understanding of hatred and hostility, which is deeply rooted within the criminal law, the latter one represents external practical (conflict, destructive) actions whereas the first one illustrates hostility without specific actions. The criminal law warrants five kinds of hatred or hostility motives: political, ideological, racial, national, religious hatred or hostility, as well as hatred or hostility towards any social group. These kinds partially overlap in their content, which requires their correct definition. In order to improve the criminal legislation the authors analyzed the disadvantages of the legislation of the Republic of Tajikistan and made certain suggestions.
\end{abstract}

\section{Introduction}

Counter-religion and counter-extremism efforts are urgent issues demanding law enforcement agencies to take stringent measures and coordinated actions aimed to prevent and suppress religious extremism.

Today terrorism and extremism became the most dangerous global phenomenon preventing smooth development of international relations, destabilizing safety of many regions and entire countries.

According to many experts, terrorism and extremism represent an asymmetrical response to global challenges, a reaction of the emerging postmodern 'network' world organization to pressure from traditional 'hierarchical' structures managing global processes.

According to projections, in 2015 the income per capita across 56 countries of the world will be less than 5 thousand dollars. Nearly 3 billion people $(41 \%$ of the entire population) will live in these countries. Hunger, blatant poverty, especially against the background of welfare growth among advanced countries, will form a strong negative aspect of the world economy at the beginning of the 21 st century. Among key parameters of global development the developed and rich countries will face an urgent need to create conditions for sustainable development of the poorest countries mainly led by the humanitarian viewpoint. The fear of uncontrolled immigration, growth of drug trafficking and terrorism in these countries will most likely force rich countries to develop and implement the economic development programs in poor countries.

The legal literature indicates that there are no clear distinctions between terrorism and extremism. Perhaps,

\footnotetext{
Corresponding author: valijon05@mail.ru
}

due to such uncertainty the state often ignores the relation between these phenomena. Currently, the efforts of law enforcement agencies on counterterrorism do not serve as a warning but as a reaction to already committed illegal acts. The fight against extremism in some CIS countries is generally confined to suppression of terrorist activity while terrorism prevention shall become the main focus of such efforts since the political power purely relying on its authority to counteract terror and not fully utilizing diverse political and legal mechanisms of its prevention and suppression, has no future.

\section{Problem Statement}

The problem of counter extremism in a society, especially among young people of Tajikistan is among the major tasks since the government bears responsibility for compliance and protection of rights and freedoms of humans and citizens (Article 5, Constitution of the Republic of Tajikistan).

The concept of 'radicalism' typial for social sciences means both conscious and unconscious extremity in views and actions (i.e. the assessment of extremity depends only on sociocultural level of individual development and its social conditions). Similar to any other extreme phenomenon, radicalism may be prosocial and anti-social. It should be considered that in severe crisis conditions (one of the largest is being developed in all countries now) the radical social elements holding extreme views possess the maximum destructive potential able to change the development trajectory of a society. This quality of radicals, the majority of which is traditionally composed of young people, for many centuries has been provoking the idea 
to use them for power struggle by groups claiming for such power. The attribution of political concept to words and actions of radical groups regardless their personal interests and needs turns diverse youth groups into the tool of power struggle, i.e. into extremist groups and associations within the context of current legislation. Natural escalation of radicalism (the boundary of 'extreme' is shifted from words to actions and such 'actions' eventually result in violence) during political struggle inevitably forms the ideology and practice of legitimacy of any violent actions in fight for the 'bright future'.

If the influence of destructive forces with regard to both internal and external impact on Tajikistan during the recent years is defined in theses, then they can be described approximately within the following time frames:

The first period -1990 , February events leading to the first human losses in Dushanbe;

The second period - 1991, rallies organized by new social, political and parochial organizations, groups;

The third period - beginning of civil opposition and mass fratricidal war - 1992-1994;

The fourth period - beginning of negotiation process and signing of the Treaty of Peace and National Consent - 1994-1997, attempts to interrupt the negotiation process by supporters of internal and external forces;

The fifth period - a series of terrorist attacks by gangs of groups and paramilitary forces, which refused to sign and accept the Treaty of Peace and National Consent, and liquidation of remained illegal armed groups - 2001-2002 years;

The sixth period - spate of new radical organizations and terrorist attacks in Dushanbe, in Sughd region 2002-2009;

The seventh period - recruitment of young people in various new radical terrorist organizations and participation of certain citizens of the Republic of Tajikistan in the Syrian Civil War as part of ISIL, escalation of illegal armed groups on the Tajik-Afghan border (on the Afghan side) - 2013-2015.

\section{Purpose of the Study}

The purpose of the study is to identify problems of applying the anti-extremism and anti-terrorism legislation of Tajikistan. This purpose implies not only the analysis of the existing legislation, but also the conditions aimed to update the forms of counterextremism and counter-terrorism in the conditions of the Republic of Tajikistan.

\section{Research Methods}

The methodology of the study is based on complex and system approaches. It also includes the methods of analysis, synthesis, generalization, logical and legal (dogmatic), comparative and legal, historical and legal approaches. The study is built upon works of Kurbonzod B.Sh. [2], Laqueur W. [3], Petryanina A.V. [4], etc. The study of extremism also overlaps with the issues of discrimination, including linguistic discrimination, which was analyzed by Iskandarova et al [1].

\section{Results and Discussion, Findings}

In recent years four external threats began to exert direct influence on national and regional security of the Central Asian states:

1. drug trafficking, drug expansion or drug menace;

2. illegal armed forces, radical and terrorist organizations generally recruiting young people, ideological opposition and ideological sabotage;

3. increase in illegal small arms (in the Middle East), illegal arms trade, control over small arms and ammunition and risk of their transportation to the Central Asian countries;

4. cyberwar, information and psychological propaganda of youth in the Republic of Tajikistan and the Central Asian states.

Having gained its international significance, terrorism and extremism cannot but affect the Republic of Tajikistan (RT).

Since 2006, such organizations as Al-Qaeda, East Turkestan Islamic Movement, Turkestan Islamic Movement (TIM), Taliban, Muslim Brotherhood, Lashkar-e-Taiba, Islamic society of Pakistan, Dzhamoati Tablig, Sozmoni Tabligot, Tochikistoni Ozod, Hizb utTahrir are under ban of the Supreme Court of Tajikistan.

Further efforts to reduce the level of radicalization were adopted after the official statement saying that since 2011 more than one thousand Tajiks have joined the militants in Syria and Iraq.

Thus, according to statistics of the RT Main Information Analysis Center of the Ministry of Internal Affairs, during 2004-2016 over 271 extremist crimes were recorded in the republic, including 3 in 2010, 1 in 2011, 2 in 2012, 13 in 2013, 43 in 2014, 112 in 2015 and 97 in $2016\{1$, P.4 $\}$.

To counteract extremism and terrorism, Tajikistan adopted the Law "On Combatting Terrorism" $\{2\}$ on 16 November 1999 and the Law "On Combatting Extremism" $\{3\}$ on 8 December 2003. Besides, on 12 November 2016 the republic approved the National Strategy of the Republic of Tajikistan on counterextremism and counter-terrorism for 2016-2020 \{4\} stipulating the main priority directions on counterextremism and counter-terrorism.

Nevertheless, anti-terrorism and anti-extremism legal acts of Tajikistan include some problems concerning their application. Let us consider some of them.

First, despite the importance of counter-terrorism the anti-terrorist legislation of Tajikistan does not consider the uniform understanding of terrorism. The analysis of available legal (and not only) literature allows "identifying from 100 to 200 concepts of terrorism and extremism, however neither of them was recognized as a classical concept". In this respect the authors cannot but agree with American scientist W. Laqueur defining terrorism as "the term overloaded with concepts, which results in failure to develop a comprehensive and objective definition of terrorism. Such definition does not exist and will not be found in the near future" $\{5$, $13\}$.

Second, the definition of extremism established in the anti-extremism legislation of Tajikistan represents 
almost a complete textual reproduction of the concept of extremist activity, which is contained in the initial edition of the anti-extremism legislation of the Russian Federation dated 2002. Moreover, the Law of RT "On Combatting Extremism" (Article 3) describes extremism as "manifestation by legal entities and individuals of extreme forms of actions appealing to destabilization, change of constitutional system in the country, seizure of power and its authorization, racial, national, social and religious agitation". This norm conflicts Article 22 of the Criminal Code of RT, according to which only sane natural person $\{6\}$ but not the legal entity is subject to criminal liability.

Third, at present the legislation of Tajikistan ambiguously treats the concepts of 'extremist crime' and 'crime of extremist activity'. Moreover, the laws and regulations define the above notions similarly to such terms as 'crime of extremist character' and 'terrorist activity'.

Thus, the Law of RT "On Combatting Organized Crime" $\{7\}$ identifies the term 'extremism' as the concept of 'extremist activity' (Art. 5). In turn, the Laws of RT "On Political Parties" (Art. 4) \{8\} and "On National Security Structures of RT" (Art. 15) \{9\} apply the concept of 'extremist activity'. The heading of Article 15 of the above law says: "Combatting Terrorist Activity and Organized Crime", however the text itself contains such statements as 'terrorist and extremist activity', and then 'organized crime'.

The same situation may be observed in case of the Uniform Concept of the Republic of Tajikistan on Combatting Terrorism and Extremism $\{10\}$ (Section 5 item 2; Section 10 item 2; Section 3 item 2, 3, 4), the Concept of Cooperation of the CIS Member States in Combatting Terrorism and other Violent Manifestations of Extremism \{11\} (Section 7 item 1; Section 4; Section 9; Section 15 item 2; Section 2; Section 3; Section 6; Section 8 item 3; Section 4 item 4), the Concept of Criminal and Legal Policy of RT $\{12\}$ (Section 8 item 2) where in one case it states 'extremist activity' and in the other - 'activity of extremist character', i.e. the terms listed above are used several times as synonyms.

Another problem, which is worth paying attention, is lack of systematization and unification of religious education in the Republic of Tajikistan. Uncontrolled departure of Tajikistan citizens from the country in recent decades with their subsequent religious education abroad resulted in low level of education of local Muslim spiritual servants. Low education of confessors affects the quality of education in madrasah. Generally students study a short course of ceremonies, superficially get acquainted with the Islamic law, partially study the issues of worship, partially Islam history, gain some knowledge of Arabic. The situation becomes even worse due to the fact that the clergy is not able to resolutely and efficiently react to manifestations of religious extremism believing that over some time nonconventional religious trends in Tajikistan will recede into the past. However, the recent events demonstrated just the reverse. Several various directions of youth extremist organizations appeared recently. Despite the apparent external discrepancy, they fit within the logic of any system, passing the stages of formation, maintenance, stabilization and further development in their urge to avoid chaos and disappearance.

Unlike traditional extremist groups of various level of organization and structure the majority of youth extremist organizations are rather sensitive and unstable. They function around norms not fixed in charters and guidelines and arise spontaneously in the course of communication therefore are perceived by all members and deeply rooted thus transforming into individual specific attitudes and value orientations. Nonconformists are characterized by various levels of organization. Quite often youth associations are unstable, do not have welldefined structure and change their configuration.

The age range of active members of extremist organizations of such type is generally from 14 to 35 years with organizational and administrative unit composed of certain senior actors. Teenagers and persons that have not reached their mature age yet but have clear separatist views are considered the most active representatives.

Thus, unlike traditional complex associations there is a clear tendency among young extremists towards association by the network principle implying high independence of network cells (youth extremist groups).

With new forms of activity of extremist groups, their organizations and communities may change the role of their participants, in particular the organizer and the leader. The organizer does not always acts as the leader, which position for various reasons may be taken by another person.

Religious extremism is similarly dangerous since it often implies illegal armed groups, organized criminal organizations specializing in terrorist crimes. However, religious extremism is not constraint by actions of certain terrorist and extremist organizations.

As a rule, participants of extremist groups and organizations record their illegal acts using videos and photos, and then place them on corresponding websites in the Internet. Such websites are actively used by extremist groups, organizations and associations to promote their activity, to justify their actions, to disseminate data on their methods, for reconnaissance purposes, to recruit new members and collect donations. Quite often the extremist and terrorist groups affiliated to them create 'short-lived websites' thus changing their formats and addresses, which complicates official recording of their illegal activity in electronic space.

Rapid development of information technology leads to the fact that many social phenomena find immediate reflection in the so-called virtual worlds, i.e. in information environment with mass media, global computer telecommunication networks and systems. The increasing criminal control over these spheres poses extremely high danger to society. The development of the Internet, which does not use earlier applied mechanisms and principles of information environment control, opened up opportunities for extremists to carry out anonymous and unpunished promotion of criminal activity.

The extremist organizations consistently master cyberspace. Recruiters are active within networks 
through a wide use of information and manipulative mechanisms. Their main task is to make their image the most attractive to the young part of the Internet users and whenever possible to recruite the maximum number of them. In both cases there is no direct contact between people, therefore all manipulative tools are utilized without restrictions resulting in unconsious actions of the majority of website users, which do not understand that they take part in extremist activity. The search for candidates is accordingly carried out at corresponding forums, blogs and in cybercommunities presenting interest to extremist organizations, which identifies the most active participants able to competently and intelligibly express their thoughts and able to convince and argue their point. When attracting such persons to cooperation the recruiters apply 'an intelligent hook' and the candidates shall solve a challenging but rather interesting intelligent task. By solving it they do not only help the extremist organization but also undergo testing for suitability. Alternatively, their entire activity in the organization can be focused on the solution of similar intelligent tasks or they can be involved in pure unwitting propaganda.

New information technologies substantially promoted the formation of such organizations, made them manageable and lifted limits on the number and geography of access to information. This new quality allowed applying technologies, which were simply impossible before: flashmob, contactless manipulation, individual and mass programming of certain actions.

Without any doubt the domestic youth extremist organizations are fully ready to use all 'achievements' of destructive technologies, which requires law enforcement officers to bear thorough knowledge of these innovations and to be ready to counteract. First of all this refers to 'virtual' environment. The study of domestic and foreign experience showed that there are all chances to supplement traditional forms of counteraction with major investigative measures in virtual environment, which could make it possible to increase the efficiency of combatting extremist organizations.

\section{Conclusion}

In conclusion it should be noted that human losses of Tajikistan as a result of the civil war, which mainly arose among the youth, cannot be measured in money and digital equivalents. The Republic of Tajikistan suffered the economic damage of over 7 billion dollars (in equivalent of 1990s), the country lagged behind 20-30 years, all critical social and economic objects were destructed. Tajikistan did not even suffer such destructions during the World War II. The most severe consequence of the civil fratricidal war was the death of over 150 thousand people with 50 thousand orphan children and more than 30 thousand widows remaining in the republic. The civil war affected every single family in Tajikistan and marked a deep imprint of grief and suffering, pain and separation. It resulted in over 1 million internal displacements and external refugees. After 25 years of national independence and 18 years from signing the Treaty of Peace and National Consent there are still some forces from abroad and within the country willing to play upon heartstrings of people and revive the feelings of religious, ethnic and parochial intolerance, promote ethnoegoistic, ethnocentric and ethnochauvinistic feelings and prejudices among young and naïve people. Thus, summing up the results it is possible to note that theoretical and practical aspects of the above problems will contribute to further positive improvement of anti-terrorism and anti-extremism situation in Tajikistan.

\section{References}

1. D. Iskandarova, O. Ladygina, K.Shambezoda, A. Zolotukhin, V. Abdukhamitov, Problems of linguistic discrimination in the communicative space of Tajikistan: legal, sociolinguistic and educational aspects, Journal of Social Studies Education Research 8 (3), 168-189 (2017)

2. B.Sh. Kurbonzoda, Criminal liability for organization of extremist movement in Tajikistan: dissertation. Candidate of Law Sciences. (Dushanbe, 2017)

3. W. Laqueur, The new terrorism: Fanatism and the arms of mass destruction. (N.Y.: Oxford University Press, 1999)

4. A.V. Petryanin, Conceptual bases of extremist crime prevention: theoretical and applied research (M.: Prospekt, 2016)

5. Law of the Republic of Tajikistan "On combatting terrorism" Vol. 845 of 16 November 1999, (Akhbori Majlisi Oli of the Republic of Tajikistan,1999)

6. Law of the Republic of Tajikistan "On combatting terrorism" No. 69 of 8 December 2003, (Akhbori Majlisi Oli of the Republic of Tajikistan, 2003)

7. Decree of the President of the Republic of Tajikistan No. 776, "On the national strategy of the Republic of Tajikistan on combatting extremism and terrorism for 2016-2020" of 12.11.2016. (Dushanbe, LLC Kontrast, 2016)

8. Criminal code of the Republic of Tajikistan of 21 May 1998 as amended and restated of 28.08.2017.

9. Law of the Republic of Tajikistan "On combatting organized crime" No. 1038 of 28 (Akhbori Majlisi Oli of the Republic of Tajikistan, 2014)

10. Law of the Republic of Tajikistan "On political parties" No. 680 of 13, November 1998, (Akhbori Majlisi Oli of the Republic of Tajikistan, 1998)

11. Law of the Republic of Tajikistan "On national security structures of the Republic of Tajikistan" No. 362 of 20, March 2008, (Akhbori Majlisi Oli of the Republic of Tajikistan, 2008)

12. Uniform Strategy of the Republic of Tajikistan on Combatting Terrorism and Extremism, Approved by the Decree of the President of the Republic of Tajikistan, No. 1717 of 28, March 2006.

13. Concept of cooperation of the CIS member states in combatting terrorism and other violent manifestations of extremism of 26 August 2005, Retrieved from: http://bkbopcis.ru/assets/files/...pdf

14. Concept of criminal and legal policy of the Republic of Tajikistan No. 492 of 2, November 2013, Retrieved from: http://www.mmk.tj/ru/.../concept/jinoyat 